KEYWORDS

Income

Income distribution

Bank credit market

Bank deposits

Markets

Financial services

Banks

Financial institutions

Informal sector

Adolfo Figueroa, Ph.D.

Professor Emeritus of Economics

Centrum Business School

Catholic University of Peru

$\nsim$ afiguer@pucp.edu.pe

CEPAL REVIEW 105 D DEEMBER 2011

\section{Income inequality and credit markets}

\author{
Adolfo Figueroa
}

$\mathrm{T}$

hree empirical regularities have been identified in the financial literature: bank credit markets operate with collateral, they operate with excess demand and they coexist with other forms of credit provision. In the particular case of less developed countries, the financial structure comprises the banking industry, the formal non-banking industry and the informal sector. This paper presents a theoretical model that explains all three regularities together. According to the model, wealth inequality in society is the essential factor that explains this dual-dual financial structure. The model predicts market segmentation: the wealthy and the banks constitute one market, the less wealthy and formal non-banking organizations constitute another and the poorest groups and small lenders constitute the informal sector; moreover, credit is more expensive in the latter sectors. As long as wealth inequality remains unchanged, this financial structure will prevail. The public policy implications of the model are also presented. 


\section{I}

\section{Introduction}

Three empirical regularities in the workings of bank credit markets have been identified by the literature: (1) bank credit markets operate with collateral (Berger and Udell, 1995); (2) bank credit markets operate with demand rationing (Berger and Udell, 1992; Steijvers and Voordeckers, 2009); and (3) bank credit markets coexist with non-bank forms of credit provision, which operate with higher interest rates. The third regularity is particularly significant in less developed countries (Campion, Kiran-Ekka and Wenner, 2010; Banerjee, 2003). A review of the literature failed to identify any empirical studies testing theoretical models of bank credit markets.

These three facts can be interpreted as the equilibrium conditions under which the banking industry operates. Any particular values that equilibrium prices and quantities may take in the market will satisfy those conditions. Consequently, the simplest way to refute any theoretical model of a bank credit market is to show that its predictions about the observable equilibrium conditions are inconsistent with these regularities. This paper will present a theoretical model that is able to predict all three regularities together. Of course, a complete refutation also requires a set of empirical predictions about the relations between endogenous and exogenous variables in the theoretical model, which can then be compared statistically against empirical data. That task lies beyond the scope of this paper.

Standard economics has sought to explain facts (1) and (2) by the theory of asymmetric information. The model developed by Stiglitz and Weiss (1981) is the classic presentation of the theory. According to this model, credit markets operate with rationing. The interest rate does not clear the market because loan quality, insofar as it affects bank profits, is not independent of this rate. The model does not necessarily predict equilibrium with

$\square$ The author is grateful for the valuable comments of an anonymous CEPAL Review referee. The research assistance of Paola Lazarte and Erick Vila is also greatly appreciated. excess demand, however; rationing could also take the form of excess supply. In other words, excess demand plays no role in the functioning of bank credit markets; i.e., it is not a necessity. Fact (2) implies the opposite.

At the same time, different views on the nature of credit market equilibrium coexist within the standard literature. While the credit market is treated as Walrasian in most macro-models (Barro, 1997; Krugman and Wells, 2006), it is treated as non-Walrasian by the Stiglitz-Weiss model and its followers. In his Nobel Lecture, Stiglitz (2002) even argued that equilibrium in the credit market may not exist.

What type of market is the bank credit market? This paper develops a partial equilibrium model of bank credit markets that will seek to answer this theoretical question. The assumptions of the model depart from the models utilized in standard economics in several ways in order to to explain the determination of prices and quantities as observed in bank credit markets. Without a sound theoretical basis, public policies run the risk of failure.

The paper is organized as follows. Section II presents a review of the literature on the empirical testing of partial equilibrium models of bank credit markets, which shows that this topic has been understudied. The nature of the bank credit market is presented in section III. Construction of the proposed partial equilibrium model starts in section IV, where a competitive model of bank credit is presented. The empirical predictions of the model are then developed. A non-competitive model may seem more appropriate for studying the banking industry, but we can invoke the theorem of equivalence: although competitive, monopoly and oligopoly models have different structural equations, under certain conditions they will qualitatively generate the same reduced form equations (same empirical predictions). The competitive model is the simplest; hence, bank credit markets can fruitfully be studied using a competitive market model. A dual model of credit markets that connects the banking and formal non-banking industries is presented in section V. Section VI introduces the informal credit sector and analyses its role in the functioning of the whole credit system. Section VII concludes. 


\section{II}

\section{Literature review}

In order to review the state of scientific knowledge on the bank credit market, an epistemological justification is needed. The Popperian epistemology of falsification will be the criterion utilized in this study. In the case of economics, this epistemology states that a good economic theory must produce a model from which empirically falsifiable propositions are derived; these empirical predictions should then be compared against empirical data. If predictions and data do not coincide, the model is refuted by reality; if all models of the theory are refuted, the theory is refuted; otherwise, the theory may be accepted provisionally, at the present stage of the investigation, until new data appear.

Table 1 presents the results of the literature review. The categories utilized refer to the Popperian methodology. The set of primary assumptions of each economic theory (general equilibrium theory) will be called alpha propositions. An economic theory is a family of models; therefore, the assumptions of a particular model about the functioning of the bank credit market will be called alpha prime. From this model, empirical predictions - called beta propositions - are derived about the relationships between the endogenous variables (price and quantity) and the exogenous variables, which are refutable or falsifiable. Thus, there are two types of refutable empirical predictions of the model: (a) observable equilibrium conditions, which are valid for every value that market prices and quantities may take, and (b) beta propositions.

Studies that have no epistemological justification can be characterized as having an empirical hypothesis without a theory, which will be called hypothesis

TABLE 1

The state of knowledge: testing theories about bank credit markets

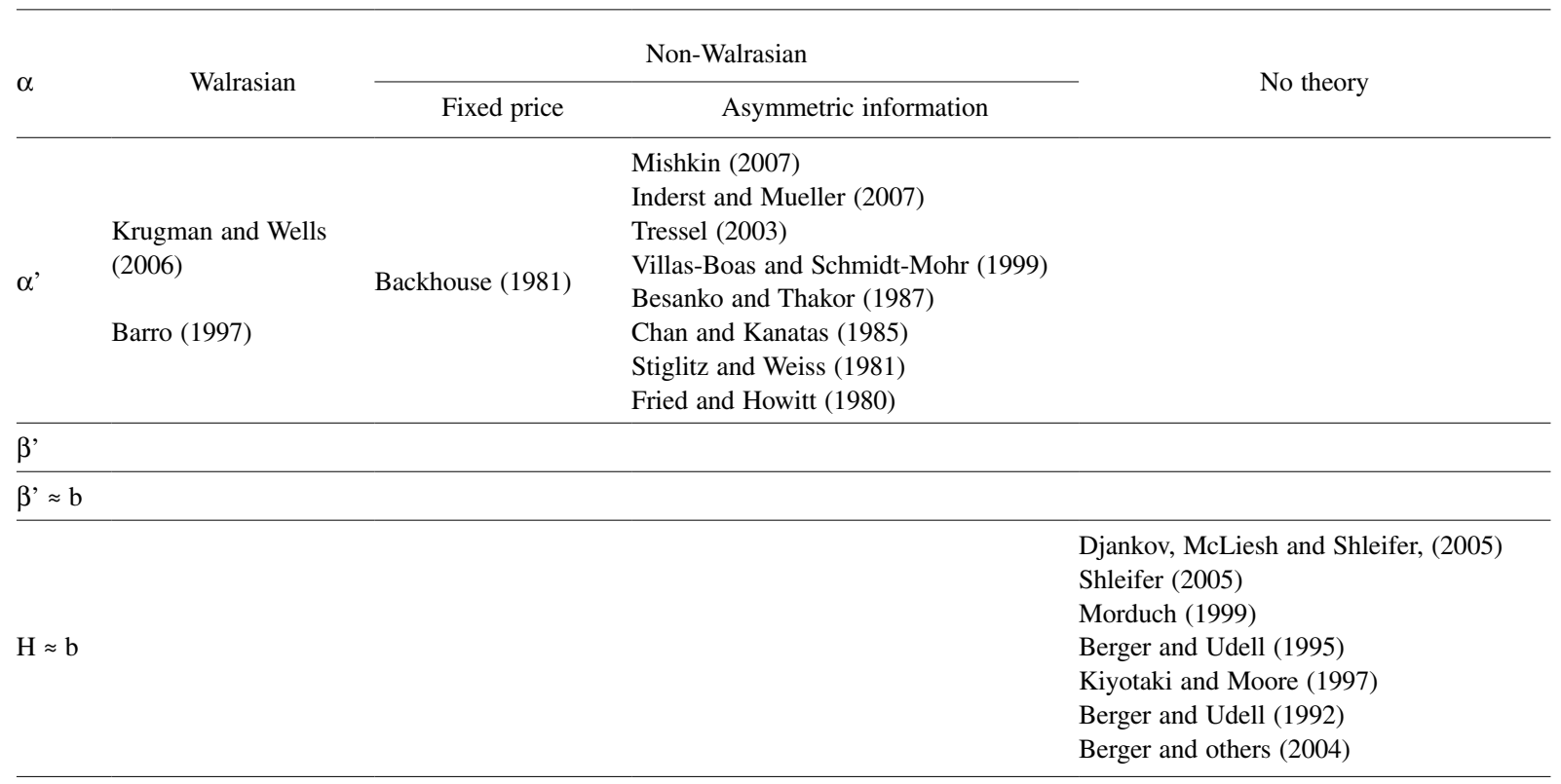

Source: selected references from the literature, reviewed using JSTOR and EconLit databases for the 1980-2008 period.

Notes: JSTOR is a multi-disciplinary digital archive of academic journals, which provides the full text of articles up to three to five years before the most recent issue (see [online] www.consorciomadrono.es/info/web/consorcio_madrono/recursos_electronicos/jstor.php). EconLit is an exhaustive bibliography of world economic literature, indexed with selected abstracts, produced by the American Economic Association. It covers over 400 journals as well as papers from edited volumes.

Symbols: $\alpha$ : primary assumptions of each economic theory; $\alpha$ ': models of the theories; $\beta$ ': empirical predictions about relationships between endogenous and exogenous variables, logically derived from the models; $\beta^{\prime} \approx \mathrm{b}$ : statistical testing of the theoretical predictions; $\mathrm{H} \approx \mathrm{b}$ : statistical testing of hypotheses without theory. 
H. This hypothesis can be tested statistically. If it passes the test, it will corroborate the hypothesis and correlations, but there will not be causality. Causality - the relationship between endogenous and exogenous variables - can only be derived from a theoretical model. Causality takes the form of a beta proposition, as indicated in table 1 .

Relevant and representative bibliographical references are shown in table 1 . This indicates the existence of a vast literature on asymmetric information models, which predict that the bank credit market operates with collateral and rationing. It also indicates the existence of a large literature applying statistical testing to hypotheses which lack a theoretical underpinning, the so-called "empirical approach". The conclusion is clear: the cells corresponding to studies where theories have been subject to the falsification process are empty (the third row). Not even the set of beta propositions has been developed (the second row). This paper proposes to help fill the gap by presenting a set of falsifiable empirical predictions logically derived from the particular model developed here.

\section{III}

\section{The nature of the credit market}

What type of market is the bank credit market? Could excess demand play any role in the functioning of credit markets? The type of transaction that takes place in a credit market involves the exchange of a sum of money now for the promise to repay later at a given interest rate. This is the nature of the credit market. Hence, this market raises the principal-agent problem. Could it operate as a Walrasian market? If individuals could always obtain the credit they desired at the prevailing market interest rate, they would not have economic incentives to repay the loan. If individuals could get credit irrespective of the effort they made to repay the loan and of their repayment history, why should they bother to repay the loan or avoid risky projects? Borrowers would not incur any cost if they defaulted. In sum, the credit market cannot operate as a Walrasian market.

What devices might banks use to discipline borrowers? A possible one would be to set the interest rate below the Walrasian price. Excess demand would thus be generated. The cost of default would now be the exclusion of bad borrowers from the credit market. Thus, the credit market could operate on a non-Walrasian basis, with excess demand.

How could this market result be attained? Assume that banks use collateral on loans as a device to discipline borrowers. The cost of default is now the loss of the collateral. Assume that the distribution of wealth in society is highly unequal. In addition, assume a financial technology that has economies of scale, so that large credits are more profitable for banks; then banks will have an incentive to do business with the wealthy segment of the market only. Total demand is now separated into two: those served by banks (the wealthy) and those excluded (the poor), who are served by the non-banking market, in which another financial technology will be used.

This is the model that will be formally developed in what follows. It will be shown that this model predicts the three empirical regularities stated above. Whether the empirical predictions of the model (relationships between endogenous and exogenous variables of the model) are refuted by data will require statistical testing.

The credit market is clearly influenced by and itself influences the rest of the economy. In order to reduce the second effect and justify the use of partial equilibrium analysis, this study will divide the bank credit market into several particular markets, which can then be analysed separately. More specifically, the partial equilibrium model is intended to explain the functioning of markets for short-term credit (for working capital) and long-run credit (for investment), in which the demand comes from firms alone. For simplicity, credit demand from households will not be part of this study. 


\section{IV}

\section{A competitive model of the bank credit market}

The particular model of the standard theory of credit markets that will be presented here seeks to explain the behaviour of prices and quantities in the banking industry. The basic assumptions of the model are the following: - agents operate in a capitalist society in which the initial individual endowment of wealth, mainly physical capital, is significantly unequal;

- market lending transactions take place in a context of uncertainty, asymmetric information and significant transaction costs;

- technology in the banking industry is such that there are major economies of scale in transaction costs when loans are large;

- collateral is the device banks use to generate a disincentive for borrowers to default.

How does the banking industry operate in such a context? This is the question that the model will seek to answer.

The banking industry is composed of two markets, the credit market and the deposit market. Banks are the financial intermediaries. Prices and quantities in the banking industry will depend upon the market structure or degree of market power of buyers and sellers. The model will assume that the banking industry operates with a market structure of perfect competition, for the reasons given in the Introduction.

\section{The behaviour of banks}

The model assumes that banks set an amount of collateral sufficient to cover the loan and the interest to be repaid; that is, loans are fully covered by the collateral. It also assumes that the enforcement of loan contracts is costless; consequently, the problems of asymmetric information are reduced significantly. The implication of these assumptions is that all potential borrowers become homogeneous in terms of risk. Therefore, banks can seek to maximize profits in the manner that is common in standard demand-supply analysis.

In a situation of perfect competition, banks are price takers in both the credit market and the deposit market. They can supply the quantity of credit they desire at the prevailing market lending interest rate; they can also acquire the quantity of deposits they desire at the prevailing market deposit interest rate. In determining the quantities they are willing to transact, banks will be guided by the desire to maximize profits.

The model then assumes the following behaviour for the case of a representative bank $k$ in the short run:

$$
\begin{aligned}
\text { Max } & P_{k}=r S_{r k}-\tilde{r} \tilde{D}_{r k}-C_{k}-F C_{k} \text { (Profits function) } \\
\text { s.t } \quad & C_{k}=f\left(S_{r k}\right), f^{\prime}>0, f^{\prime}>0 \\
& S_{r k} \leq(1-e) \tilde{D}_{r k} \\
& S_{r k}=\sum s_{k j}, \text { such that } s_{k j} \geq s_{k}^{*} \forall j=1,2, \ldots, n_{k}
\end{aligned}
$$

The first equation of system (1) is the bank's profit equation, where $P$ stands for nominal profits, $r$ for the nominal lending interest rate, $S_{r}$ for the nominal quantity of credit, $\tilde{r}$ for the nominal deposit interest rate, $\widetilde{D}_{r}$ for the nominal quantity of deposits, $C$ for the total variable cost of intermediation and $F C$ for the total fixed costs of the bank. The second equation is just the variable cost function. The third equation shows the restriction that the bank's loanable fund is net of the reserve requirement, whose rate $e$ is established by the monetary authority.

This last constraint indicates that banks set threshold values for the size of individual loanable funds by borrower (called $s$ ), which cannot be smaller than $s^{*}$. This is due to the nature of the intermediation cost faced by banks. The intermediation cost includes transaction costs and the cost of intermediation proper. The model assumes that the transaction cost per borrower is constant; i.e., it is independent of loan size. Therefore, the unit cost per dollar of lending declines with loan size up to size $s^{*}$ and then becomes constant. The bank thus has no incentive to lend money to borrowers seeking loans smaller than $s^{*}$.

In the short run, banks must determine the quantity of lending that maximizes profits. From the structural equations shown in system (1), the equilibrium condition can then be derived by differentiating the profit equation with respect to $S_{r}$. The equilibrium condition for bank $k$ then becomes:

$$
\begin{gathered}
r=\frac{\tilde{r}}{(1-e)}+f^{\prime}\left(S_{r k}\right)=M C_{k}\left(S_{r k}, \tilde{r}, e\right), \\
M C_{1}>0, M C_{2}>0, M C_{3}>0
\end{gathered}
$$


The individual bank will seek to maximize profits, which implies equalizing the market lending interest rate with the marginal cost of providing credit $(M C)$. The latter is equal to the net marginal cost of acquiring the necessary bank deposits plus the marginal cost of intermediation.

The equilibrium condition in (2) is clearly stable; consequently, the static comparative method can be applied to this equilibrium condition to derive empirical predictions for the behaviour of the representative bank. The endogenous variables include the quantities of loans and deposits. The exogenous variables include lending and deposit interest rates and the reserve requirement ratio. The capital stock of the bank is also exogenously given, but changes in it will be ignored in this shortrun model.

The effects of changes in the exogenous variables upon the endogenous variables can easily be derived from equation (2). The reduced form equations are then obtained as follows:

$$
\begin{gathered}
S_{r k}=F^{k}(r, \tilde{r}, e), F_{1}^{k}>0, F_{2}^{k}<0, F_{3}^{k}<0 \\
\tilde{D}_{r k}=\left[\frac{1}{(1-e)}\right] S_{r k}
\end{gathered}
$$

The equilibrium quantity of credit supplied by representative bank $k$ depends upon the exogenous variables of the model, as shown in equation (3a). An increase in the lending interest rate has the effect of increasing the quantity of credit supplied because it increases marginal revenue; an increase in the deposit interest rate or in the reserve requirement ratio has the effect of reducing the quantity of credit supplied because the marginal cost increases.

The bank will determine the quantity of credit supplied on the basis of the values of the exogenous variables. The required quantity of deposits will then also be determined, as a derived demand for bank deposits. This is shown in equation (4a).

The aggregate behaviour of banks will be obtained by simple addition of the equations of the individual banks, as shown in system (3a)-(4a), across all banks in the industry. Thus, equation (3) represents the market supply function of bank credit and equation (4) the market derived demand function for bank deposits.

$$
\sum S_{r k} \equiv S_{r}=F(r, \tilde{r}, e), F_{1}>0, F_{2}<0, F_{3}<0
$$

$$
\sum \tilde{D}_{r k} \equiv \tilde{D}_{r}=\left[\frac{1}{(1-e)}\right] S_{r}
$$

\section{The behaviour of households and the supply of bank deposits}

In a market economy that includes banks, the quantity of money will be equal to currency in circulation plus demand deposits. Both can be used as a means of payment. Households must choose not only the stock of money they want to hold, but also its allocation between bank deposits and cash balances.

A model of household behaviour will now be presented. There is a demand for money from households to cope with the transaction and precautionary needs that arise in a market economy. Holding cash has an opportunity cost, which is given by the deposit interest rate paid by banks. Households will therefore decide on a portfolio of cash and bank deposits to meet their demand for money.

The model will assume that households choose their portfolios on the basis of the mean return and risk of each asset, as suggested by the standard mean-variance theory. Cash may be considered an asset with no return and no risk, whereas bank deposits may be considered an asset with a positive mean return and risk. The risk includes the instability of individual banks and that of the banking system as a whole. The model also assumes the existence of a State regulatory policy involving State deposit insurance up to a certain deposit amount and the supervision of bank operations, such that the State is the lender of last resort. As far as households are concerned, all banks are thus homogeneous in terms of the risk of deposits not being returned (there are no high-risk banks and low-risk banks). Bank deposits entail risks due to the variability of interest rates, however.

An individual household's portfolio will therefore depend on the deposit interest rate and the real income of the household. The higher the interest rate paid by banks, the larger the quantity of money deposited in them; the higher the household's real income, the larger the quantities of both assets in its portfolio. If money endowment changes exogenously, households will revise their portfolios, and the effects on both cash and bank deposits will also be positive. Hence, for the representative household $h$ it follows that:

$$
\tilde{S}_{r h}=G^{h}(\tilde{r}, Y), G_{1}^{h}>0, G_{2}^{h}>0
$$


The market supply function of bank deposits will be obtained by aggregating the individual household functions. Then:

$$
\sum_{h} \tilde{S}_{r h} \equiv \tilde{S}_{r}=G\left(\tilde{r}, Y, S_{m}\right), G_{1}>0, G_{2}>0, G_{3}>0
$$

The exogenous variables in function (5) include the deposit interest rate $(\tilde{r})$ and households' income level $(Y)$. In the aggregation of micro behaviour to market behaviour, one new exogenous variable will appear. This is the central bank's money supply $\left(S_{m}\right)$, which is determined by the monetary authority and which in equilibrium must be equal to the currency willingly held by households and by banks as required reserves. The larger the money supply, the higher the excess demand for money in the hands of households and the greater bank deposits will be.

\section{The behaviour of production firms and the demand for bank credit}

The demand for bank credit will come from production firms alone (lending to households will be ignored). Two types of credit demand will be considered: to finance working capital in the short run and to finance capital accumulation in the long run.

Firms are endowed with quantities of fixed capital $(K)$. Assume that all firms produce a single good, called $\operatorname{good} B$, which has a market price $P_{b}$. Also assume that only one set of labour skills is utilized in the production of $\operatorname{good} B$ in quantity $D_{h}$ at the nominal market wage rate $P_{h}$.

Another factor of production will be introduced now: circulating or working capital. This production input is a financial fund, which firms take in the form of credit from banks and which is utilized in a fixed proportion of total output. Let $D_{r j}=v_{j} P_{b} Q_{b j}$, where $D_{r}$ is the nominal quantity of credit demanded and $v$ is the technical coefficient of working capital per unit of output value.

Firms seek to maximize profits. The behaviour of the representative firm, which is now identified as firm $t$, can be summarized as follows:

$$
\begin{array}{ll}
\operatorname{Max} & P_{t}=P_{b} Q_{b t}-P_{h} D_{h t}-r D_{r t} \\
\text { s.t } \quad Q_{b t}=g^{t}\left(D_{h t}, K_{t}\right)=\frac{D_{r t}}{v_{t} P_{b}}, g_{1}^{t}>0, g_{2}^{t}>0
\end{array}
$$

The first equation of system (6) shows the individual firm's nominal profit $(P)$, which is equal to the net value of output (net of physical capital replacement and net of working capital replacement or loan repayment) minus labour costs and minus the cost of the short-term loan. The constraint is given by the limitational production function, represented as a system of equations, which assumes that fixed capital and labour are substitutes for each other (function $g$ ) but neither is a substitute for working capital.

In the short run, firms must decide on the quantity of employment that maximizes profits. From the structural equations of system (6), the equilibrium condition can be derived by differentiating the first equation with respect to $D_{h}$. This condition is:

$$
P_{b} g_{1}^{t}\left(D_{h t}, K_{t}\right)\left[1-r v_{t}\right]=P_{h}
$$

In order to maximize profits, the individual firm must hire labour until the net value of the marginal productivity of labour, net of the cost of working capital per unit of output that is required to realize this output, is equal to the nominal market wage rate $P_{h}$.

The equilibrium condition in (7) is clearly stable; therefore, comparative statics may be applied to derive the behaviour of the individual firm. The endogenous variables of the model include $D_{h}, Q_{b}$ and $D_{r}$, while the exogenous variables include $P_{b}, K, r$ and $P_{h}$ (the technological coefficient $v$ is assumed to be invariant in the short run). The reduced form equation is obtained from equation (7). The labour demand function can be written as:

$$
\begin{gathered}
D_{h t}^{0}=L^{t}\left(P_{b}, K_{t}, r, P_{h}\right), L_{1}>0, \\
L_{2}>0, L_{3}<0, L_{4}<0
\end{gathered}
$$

where equilibrium prices and quantities are marked with a superscript zero. The derived demand for short-run credit can then be written as:

$$
\begin{aligned}
& D_{r t}^{0}=v_{t} P_{b} g^{t}\left(D_{h t}^{0}, K_{j}\right) \\
& =J^{t}\left(r, P_{b}, K_{t}, P_{h}\right) \\
& J_{1}<0, J_{2}>0, J_{3}>0, J_{4}<0
\end{aligned}
$$

The quantity of bank credit demanded by firm $j$ depends negatively upon the lending interest rate and upon the firm's other exogenous variables, as shown in equation (9). 
The quantity of bank credit demanded in the market will be arrived at by aggregating individual equilibrium quantities across all firms. Then, for a given total of $n$ firms in the bank credit market and a given distribution of capital endowments between firms such that $m$ firms have capital equal to or higher than the threshold value $s^{*}$,

$$
\begin{gathered}
\sum_{t=1}^{m} D_{r t}^{0} \equiv D_{r}^{*}=J\left(r, P_{b}, K, P_{h}, \delta\right), \\
J_{1}<0, J_{2}>0, J_{3}>0, J_{4}<0, J_{5}>0 \\
\text { Such that } K=\sum K_{t} \text { y } K_{t} \geq s^{*} \forall t=
\end{gathered}
$$$$
1,2, \ldots, m \text { and } m<n
$$

Equation (10) shows the aggregation of the quantity of bank credit demanded by production firms. But the aggregation includes only firms endowed with a large amount of capital, equal to or greater than the threshold loan size $\left(s^{*}\right)$ that banks require if firms are to be eligible for credit, as shown in system (1). The aggregate quantity of bank credit demanded $D_{r} *$ may then be called the effective aggregate demand for bank credit. Let $D_{r}$ represent the total demand for credit; then $D_{r}>D_{r} *$. Hence, small firms to the number of $(n-m)$ will be excluded from the bank credit market.

In the process of aggregation, another exogenous variable appears in the credit demand function $J$ : the degree of concentration of total physical capital among firms, the variable $\delta$. The effect of this variable is positive. If the given total stock of capital in the economy is more concentrated in the highest percentiles, the demand for credit will be higher. The reason is simple: those high percentiles of the distribution, which are already eligible for bank credit, will now account for a larger share of the capital stock. The quantity of capital that is available as collateral will then be a larger proportion of the total capital stock. In the extreme case where the whole capital stock of the economy was in the hands of one firm, the proportion of total capital available as collateral and eligible for bank credit would be $100 \%$. In the contrary extreme case where the capital stock of the economy was divided among many firms that were too small to be eligible for credit, there would be no effective demand for credit and no bank credit market.

In the long run, production firms need financing for their investment projects. Each project has an expected rate of return. Firms will take out loans to finance a project if and only if the interest rate is equal to or less than the expected rate of return. At lower market interest rates, the quantity of projects seeking financing will be greater and the long-run quantity of bank credit demanded will be higher. The reason is very simple: there will be more projects with low returns than with high returns; thus, if the interest rate were lower, projects that were not profitable before would now become so, while those that were profitable before would continue to be so.

The behaviour of production firms seeking investment financing generates a downward-sloping demand curve. This is similar to the demand curve for short-run working capital. The prices, however, will be different, i.e., there will be a short-run interest rate and a long-run interest rate in the bank credit market. They constitute two separate bank credit markets, but the same demand function (10) can be utilized to represent either case.

\section{Market equilibrium conditions}

Market equilibrium conditions can be written as equality between quantities supplied and demanded in each market. Thus:

$$
\begin{gathered}
\text { Credit market } S_{r}=D_{r}^{*}<D_{r} \\
\text { Deposit market } \tilde{\mathrm{S}}_{r}=\tilde{D}_{r}
\end{gathered}
$$

Equation (11) says that bank credit market equilibrium requires equality between the quantity of credit supplied (by banks) and the effective quantity of credit demanded (from eligible production firms, selected by banks). It is a Walrasian market in the sense that there is no excess demand in terms of the effective demand category $\left(D_{r}^{*}\right)$, but it is non-Walrasian in the sense that it operates with excess demand in terms of the total demand category $\left(D_{r}\right)$. According to the first concept, effective demand and supply are not independent, as effective demand is influenced by bank behaviour. If banks changed the threshold values for eligibility, effective demand would change even though total demand remained constant. The bank credit market may thus be called a quasi-Walrasian market.

The Stiglitz-Weiss model assumes a relationship between expected returns to the bank and the lending interest rate, in the form of an inverted U. Thus, an optimal interest rate exists and banks choose this as the market price, which is independent of quantities, and in this way the credit market can operate with either excess demand or excess supply. Collateral is then introduced in a manner that does not fully protect the loan and interest, so that asymmetric information 
continues to be the main feature of the model. Collateral may, under certain conditions, reduce the expected rate of return for banks. The same argument is also found in Manove, Padilla and Pagano (2001). In the present paper, the model assumes full collateral, implying that the effective demand curve is one of the essential market relationships; hence, prices and quantities are determined simultaneously in the credit market.

Equation (12) shows the equilibrium condition of the bank deposit market. The quantity of deposits supplied (by households) must be equal to the quantity of deposits demanded (from banks). This is a Walrasian market.

The banking industry model thus has four structural equations: (3), (4), (5) and (10). They should be sufficient to solve for the four endogenous variables, two prices and two quantities: $r, \tilde{r}, Q=S_{r}=D_{r}$ and $\tilde{Q}=\tilde{S}_{r}=\tilde{D}_{r}$. The equilibrium conditions shown in system (11)-(12) can then be rewritten as:

$$
\begin{gathered}
\text { Credit market } F(r, \tilde{r}, e)=J\left(r, P_{b}, P_{h}, K, \delta\right) \\
\text { Deposit market } \mathrm{G}\left(\tilde{\mathrm{r}}, \mathrm{S}_{m}, Y\right)=\left[\frac{1}{1-e}\right] S_{r}
\end{gathered}
$$

The first condition shows the transaction between banks and firms, the second the transaction between banks and households; in each case, the quantity supplied must be equal to the quantity demanded. The aggregate behaviour of production firms is represented by function $J$ and that of households by function $G$.

The competitive market equilibrium is represented in figure 1. The structural equations are represented by the supply and demand curves in the credit and deposit markets. The parameters of each credit curve are fixed. Then the equilibrium condition determines the equilibrium values of the lending interest rate and the quantity of credit; the latter determines the equilibrium quantity of bank deposits, which will be forthcoming at a particular value for the deposit interest rate, which should be equal to the initial value for equilibrium to be attained in both markets. The two supply-demand curves are interdependent; hence, the equilibrium values of prices and quantities in the credit and deposit markets are determined simultaneously.

It will be most convenient for what follows to solve the system (11)-(12) using the corresponding inverse demand and supply functions, which are called demand and supply curves. Demand and supply functions are monotonic by assumption. This assumption is sufficient for us now to use the inverse functions, which are also monotonic. Hence:

Credit market:

$$
\begin{aligned}
& \text { Supply curve } r=F^{\prime}(Q, \tilde{r}, e) \\
& F^{\prime}>0, F_{2}^{\prime}>0, F_{3}^{\prime}>0
\end{aligned}
$$

Demand curve $r=J^{\prime}\left(Q, P_{b}, P_{h}, K, \delta\right)$

$J_{1}^{\prime}<0, J_{2}^{\prime}>0, J_{3}^{\prime}<0, J_{4}^{\prime}>0, J_{5}^{\prime}>0$

Deposit market:

$$
\begin{aligned}
& \text { Supply curve } \tilde{\mathrm{r}}=G^{\prime}\left(\tilde{Q}, S_{m}, Y\right) \\
& G_{1}^{\prime}>0, G_{2}^{\prime}<0, G_{3}^{\prime}<0
\end{aligned}
$$

Derived demand $\tilde{Q}=\left[\frac{1}{1-e}\right] Q$

\section{FIGURE 1

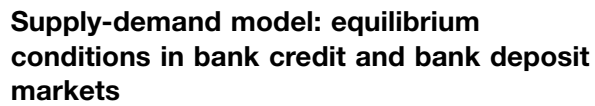

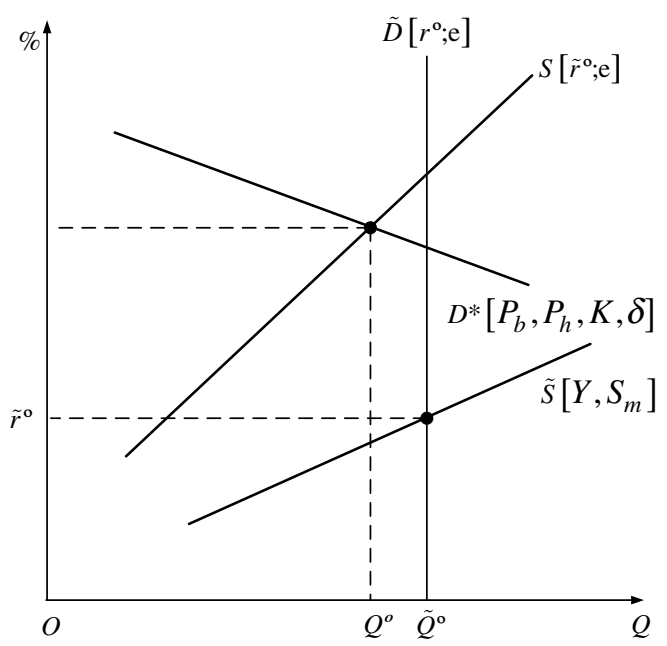

Source: Prepared by the author.

Symbols: $S$ : bank credit supply curve; $D$ : effective bank credit demand curve; $\tilde{S}$ : effective bank deposit supply curve; $\tilde{D}$ : derived demand for bank deposits; $r$ : nominal lending interest rate; $\tilde{r}$ : nominal deposit interest rate. 
Equation (18) can be inserted into equation (17). Then:

$$
\begin{aligned}
& \tilde{\mathrm{r}}=G^{\prime *}\left(Q, e, S_{m}, Y, \delta\right) \\
& G_{1}^{\prime *}>0, G_{2}^{*}>0, G_{3}^{\prime *}<0, G^{\prime *}<0, G^{\prime *}{ }_{5}<0
\end{aligned}
$$

Equation (17a) can now be inserted into the credit supply curve, equation (15):

$$
\begin{aligned}
& r=F^{\prime}\left(Q, G^{*}\left(Q, e, S_{m}, Y, \delta\right), e\right)=H^{\prime}\left(Q, e, S_{m}, Y, \delta\right) \\
& H_{1}^{\prime}>0, H_{2}^{\prime}>0, H_{3}^{\prime}<0, H_{4}^{\prime}<0, H_{5}^{\prime}<0
\end{aligned}
$$

Finally, the credit market equilibrium condition shown in (13) above now becomes:

$$
\begin{gathered}
H^{\prime}\left(Q, e, S_{m}, Y, \delta\right)=\left(Q, P_{b}, P_{h}, K, \delta\right) \\
H_{1}^{\prime}>0, H_{2}^{\prime}>0, H_{3}^{\prime}<0, H_{4}^{\prime}<H_{5}^{\prime}<0 \\
J_{1}^{\prime}<0, J_{2}^{\prime}>0, J_{3}^{\prime}<0, J_{4}^{\prime}>0, J_{5}^{\prime}>0
\end{gathered}
$$

Equation (19) constitutes the core of the system. This single equation will determine the equilibrium value $Q^{O}$, given the values of the exogenous variables of the entire system, and will thus generate the first reduced form equation of the model. The other three endogenous variables are solved by substitution, i.e., by substituting $Q$ with the reduced form equation of $Q^{O}$ in structural equations (15a), (17a) and (18).

\section{Empirical predictions of the competitive model}

The equilibrium condition of the core of the system, represented in equation (19), is clearly stable: the consolidated supply curve has a positive slope $\left(H^{\prime}{ }_{1}>0\right)$ and the demand curve has a negative slope $\left(J^{\prime}{ }_{1}<0\right)$. The comparative statics method can therefore be applied to the equilibrium condition to derive the empirical predictions of the model. The variables of the model are:

$$
\begin{array}{ll}
\text { Endogenous } & r, \tilde{r}, Q, \tilde{Q} \\
\text { Exogenous } & Y, S_{m}, e, P_{b}, P_{h}, K, \delta
\end{array}
$$

The causality relationships (relationships between endogenous and exogenous variables in the reduced form equations) may be obtained in two different ways. The two structural equations (15a) and (16) may be utilized to find the partial derivatives with respect to each of the exogenous variables and solve for the sign of the partial derivatives from the corresponding matrix. Alternatively, the partial derivatives may be found first in equation (19), the core equation of the system, and then the algorithm follows in structural equations (15a), (17a) and (18), incorporating the results obtained into the core equation in each case.

However, the derivation of the causality relationships can be made graphically because the system is very simple and formal derivation is unnecessary. The graphical representation of the comparative statics for the credit market as the core of the system is shown in figure 2 . The effects of increases in each exogenous variable upon the equilibrium price and quantity through shifts in the supply curve are shown in panel (a), while those arising through shifts in the demand curve are shown in panel (b). The corresponding effect upon the equilibrium price and quantity in the deposit market is determined only through substitution using structural equations (17a) and (18).

The set of empirical predictions of the model are summarized in matrix form in table 2 . These predictions can then be subjected to the process of empirical refutation. Failure in one cell is sufficient to refute the model; if no cell fails, then there is no reason to reject the model and it may be accepted at this stage of the research. It can be shown that under certain standard assumptions, other market structures (monopoly and oligopoly) will generate the same matrix.

Statistical testing of the empirical predictions presented in table 2 is beyond the scope of this study. The literature review summarized in table 1 above presented six empirical studies that carried out hypothesis testing. Unfortunately, none of these studies sought to establish statistical relationships for the variables included in the model presented here; if they did, their results could

TABLE 2

Matrix of empirical predictions logically derived from the competitive model

\begin{tabular}{lcccccccc}
\hline & \multicolumn{8}{c}{ Exogenous variables } \\
\cline { 2 - 7 } Endogenous variables & $Y$ & $S_{m}$ & $e$ & $P_{b}$ & $P_{h}$ & $K$ & $\delta$ \\
\hline$r$ & - & - & + & + & - & + & $?$ \\
$\tilde{r}$ & $?$ & $?$ & $?$ & + & - & + & $?$ \\
$Q$ & + & + & - & + & - & + & + \\
$\tilde{Q}$ & + & + & $?$ & + & - & + & + \\
\hline
\end{tabular}

Source: Prepared by the author.

Symbols: r: interest rate on bank loans; $\tilde{r}$ : interest rate on bank deposits; $Q$ : quantity of bank credit; $\tilde{Q}$ : quantity of bank deposits; $Y$ : national income; $S_{m}$ : money supply; $e$ : reserve requirement rate; $P_{b}$ : price level; $P_{h}$ : nominal wage rate; $K$ : stock of physical capital; $\delta$ : degree of wealth concentration. 
(a)

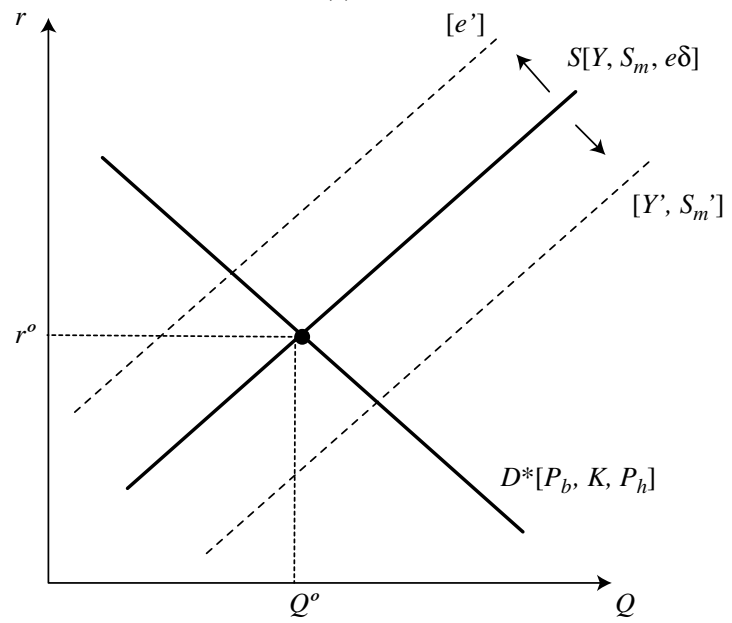

(b)

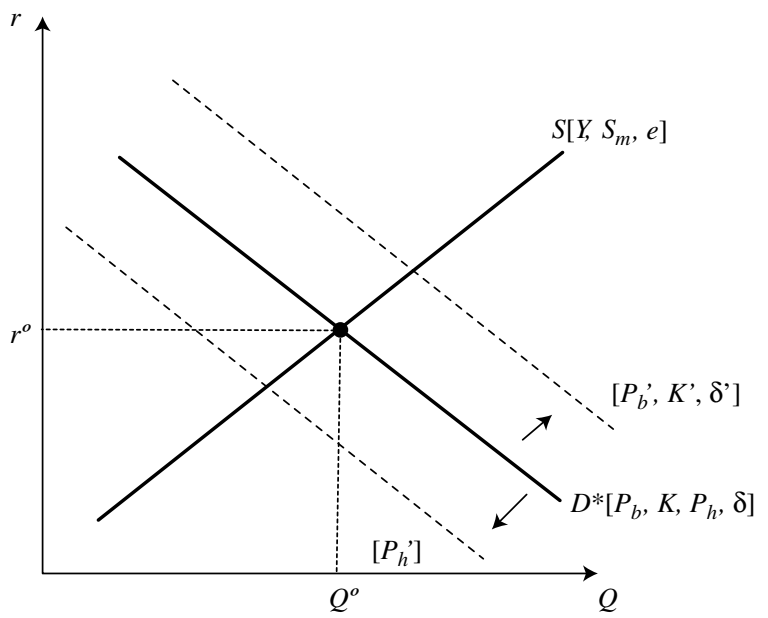

Source: Prepared by the author.

Notes: Graph (a): an increase in exogenous variable $Y, S_{m}$ or $\delta$ shifts the consolidated bank credit supply curve outward, but an increase in $e$ shifts the curve inward. Graph (b): an increase in exogenous variable $P_{b}, K$ or $\delta$ shifts the bank credit demand curve outward, but an increase in $\mathrm{P}_{\mathrm{h}}$ shifts the curve inward.

have been used as first indicators of consistency or refutation of some of the signs shown in table 2. Those studies were interested in other variables, such as bank concentration, credit rationing, the direct impacts of micro-credit, macro-credit as a ratio to gross domestic

\section{$\mathrm{V}$}

\section{A dual model}

The banking industry model will now be extended to explain why the banking industry and formal non-banking financial organizations coexist. This new model will be called the dual model.

Non-banking organizations are small in size and are usually called micro-financial organizations, examples being cooperatives, credit unions and small State and private-sector financial organizations. They are also State-regulated.

Consider that prices and quantities in the banking industry have already been determined. The equilibrium in the bank credit market is with excess demand. Those excluded from the bank credit market are the less wealthy, product (GDP), the role of the legal system and credit in macroeconomic cycles. Empirical research is therefore expected to be encouraged by the results presented in table 2, which constitute a set of hypotheses with theoretical backing. and they will seek loans in the non-banking credit market; therefore, the demand curve for non-banking organizations will also be determined. Non-banking organizations are also financial intermediaries and thus need to have deposits to make their loans. They will use several incentives. One is to establish a requirement for deposits to be made as a condition of eligibility for loans, so potential borrowers of small loans will have an incentive to deposit their funds in the non-banking organization instead of in the banking industry (the case of a cooperative is a clear example); another is to pay an interest rate higher than banks pay. The deposit supply curve in the non-banking organization will thus 
be determined. This is a rising curve, and it starts at the value given by the deposit interest rate prevailing in the banking industry, because this is the opportunity cost of those funds.

How are prices and quantities determined in the non-banking industry? Financial intermediaries in the non-banking financial market are also profit maximizers. To generate and maximize profits while supplying small individual loans, they must use financial intermediation technologies different to those of the banking industry; in particular, transaction costs will be smaller due to more personal relations with borrowers. The competitive equilibrium in the non-banking industry will be determined much as in the banking industry, by the interaction of supply and demand.

The equilibrium situation of the dual financial market is illustrated in figure 3. Prices and quantities are first determined in the banking industry (first panel), which implies exclusion of potential borrowers, who seek credit in the non-banking industry and determine the demand curve $D_{n}$, shown in the second panel. The supply curve of deposits in the non-banking market is represented by the rising supply curve $S_{n}$, which starts at the bank deposit interest rate. The equilibrium quantity and price in the credit market are determined by the intersection of the demand and supply curves at point B. Given the reserve requirement rate, the equilibrium quantity and price in the deposit market that are consistent with point $\mathrm{B}$ are given at point B'. In the non-banking sector, prices and quantities in the credit and deposit markets are thus determined simultaneously.

Several predictions of this dual model of financial markets can now be derived. First, the banking and nonbanking industries operate as separate but connected markets. The overall equilibrium is sequentially determined: equilibrium in the non-banking industry is determined once the equilibrium in the banking industry is known; in particular, changes in the deposit interest rate in the banking industry will change the equilibrium values of price and quantity in the non-banking industry. Second, the duality of the market is associated with wealth distribution: the wealthy and the banks constitute one financial market, whereas the poor and the nonbanks constitute the other. Third, in equilibrium, both prices (credit and deposit interest rates) are higher in the non-banking industry than in the banking industry. These predictions are consistent with the regularity (3) described in the Introduction.

Fresh empirical evidence for Peru is shown in table 3. Average prices and average quantities in the banking system over the period 2003-2008 indicate what the model predicts: (a) in the credit market, banks supply credits of larger average size than non-banks and charge lower interest rates; (b) in the deposit market, banks attract deposits of larger average size than nonbanks and pay lower interest rates. The model is thus able to explain fact (3).

FIGURE 3

Sequential general equilibrium in dual financial markets

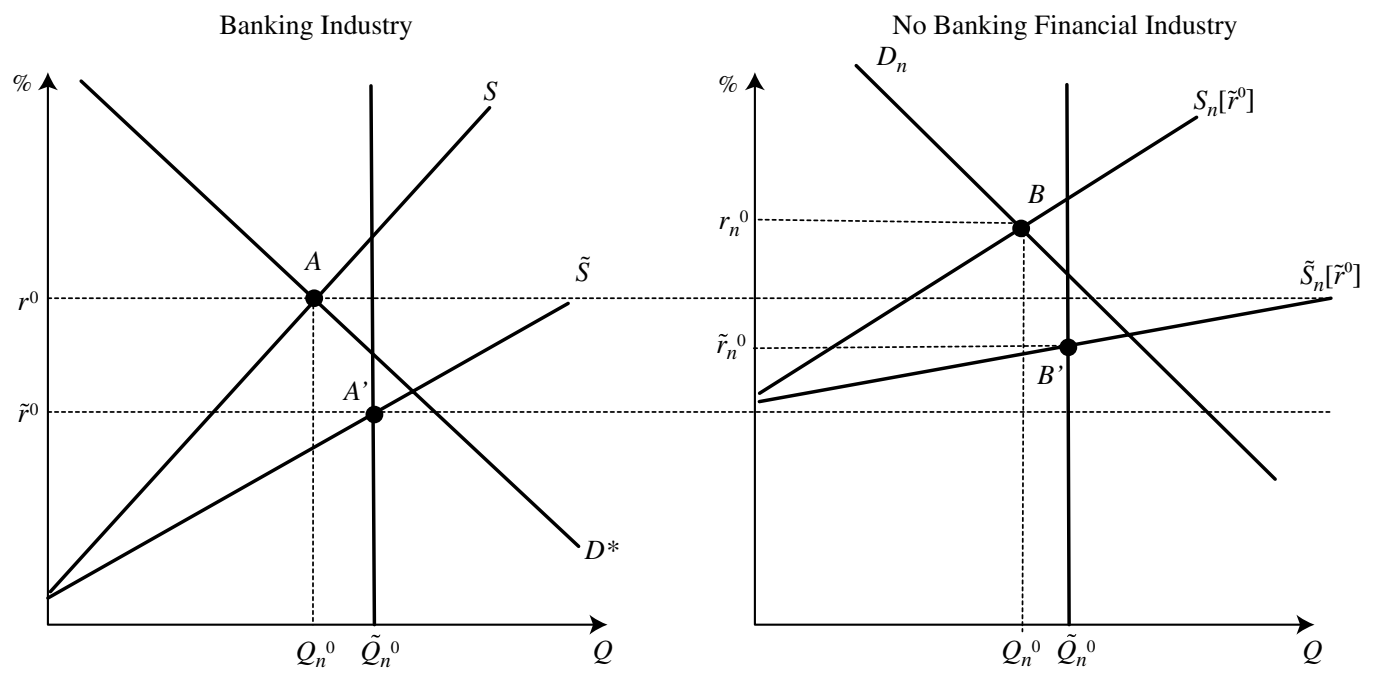

Source: Prepared by the author. 
TABLE 3

Peru: prices and quantities in credit and deposit markets, 2003-2008

(Nominal annual interest rates, monetary values in nominal new soles)

\begin{tabular}{|c|c|c|c|c|c|}
\hline \multirow[t]{2}{*}{ Credit market } & \multirow[b]{2}{*}{ Term/Currency ${ }^{\mathrm{a}}$} & \multicolumn{2}{|c|}{ Banks $^{c}$} & \multicolumn{2}{|c|}{ Non-banks ${ }^{\mathrm{c}}$} \\
\hline & & $q^{\mathrm{b}}$ & $r$ & $q^{\mathrm{b}}$ & $r^{\mathrm{d}}$ \\
\hline \multirow{3}{*}{ Large loans } & Short-term NC & \multirow{3}{*}{550496} & 14.50 & \multirow{3}{*}{$92497^{\mathrm{e}}$} & 42.79 \\
\hline & Long-term FC & & 11.73 & & 21.28 \\
\hline & Short-term FC & & 11.60 & & 22.89 \\
\hline \multirow{4}{*}{ Small loans } & Long-term NC & \multirow{4}{*}{$10270^{\mathrm{e}}$} & 38.94 & \multirow{4}{*}{4813} & 47.77 \\
\hline & Short-term NC & & 37.58 & & 55.75 \\
\hline & Long-term FC & & 25.30 & & 26.84 \\
\hline & Short-term FC & & 24.29 & & 29.65 \\
\hline \multirow[t]{4}{*}{ Deposit market } & & $q^{\mathrm{b}}$ & $r$ & $q^{\mathrm{b}}$ & $r^{\mathrm{d}}$ \\
\hline & Long-term NC & \multirow{3}{*}{9140} & 5.85 & \multirow{3}{*}{3344} & 12.06 \\
\hline & Long-term FC & & 4.22 & & 7.77 \\
\hline & Short-term FC & & 2.88 & & 3.36 \\
\hline
\end{tabular}

Source: author's calculations. The primary source is data published by the Superintendency of Banks and Insurance (sBs), the State banking regulator of Peru, on its website (www.sbs.gob.pe), last accessed on 16 June 2010. Regarding calculation methods:

(i) Average quantities of credit per bank or cooperative (caja) ( $q$ ) refer to lending to firms; original data refer to debt stock at the end of the year; data on credit distribution by term/currency are unavailable.

(ii) The original interest rate $(r)$ data are daily; for calculations, the rates of the last day of the month were utilized, and then the averages for the five years from May 2003 to April 2008 were calculated.

(iii) Large loans are those higher than US\$20,000 up to 2003 and US\$ 30,000 thereafter, as identified by the sBS.

Notes:

a Long- (short-)term: average rates for credits or deposits longer (shorter) than 360 days in local currency (NC: Peruvian new soles) or foreign currency (FC: dollars).

b Average per year and per borrower or depositor.

c The banking system includes 20 banks, and the non-banking system is represented by two types of microfinance organizations: cajas municipales (12) and cajas rurales (10).

d Interest rates are lower in the non-banking sector than in the banking sector in all cases, as indicated by the Kruskal-Wallis non-parametric test at a $5 \%$ significance level.

e This category represents a small fraction of the total credit supply within the group (vertical or horizontal).

\section{VI}

\section{A dual-dual model}

Will there be excess demand for credit once the nonbanking market has been introduced? The existence of the so-called informal credit sector in less developed countries indicates that the answer is yes. The dual credit market is State-regulated and excludes a particular group of potential borrowers: those with very few or no assets, the poorest groups in society. Consider particularly the group of self-employed workers in urban or rural areas who need small loans and for short periods for their small businesses or small farms. On the supply side, this sector includes individuals (including "loan sharks" as well as friends and relatives) and some organizations, such as non-governmental organizations (NGOS).

One of the characteristics of the informal credit sector is that it is not State-regulated. Contracts are thus informal. Another is that the suppliers of funds are not financial intermediaries, as they mostly use their own funds. The last characteristic is that credit provision takes the form of both market and non-market transactions. The latter consist of exchanges between friends and relatives and are 
based on rules of reciprocity, social control mechanisms, social networks and family ties. The use of credit as part of multiple exchanges of goods is also common (credit provided to farmers by merchants, for example) and can be seen as a type of interlocking transactions that are hard to define as pure market transactions. For these reasons, it is more appropriate to call it the informal credit sector, rather than market. The construction of theoretical models for this very heterogeneous sector is something that needs to be done. After reviewing a large set of empirical surveys and studies on informal credit, Banerjee (2003) underscored "the significance of developing a proper theory" (p.10).

\section{VII}

\section{Conclusions}

A new model of the standard theory of bank credit markets has been developed in this paper. The model predicts that the equilibrium conditions under which the banking industry operates include: the use of collateral, equilibrium with excess demand and coexistence with a non-banking financial sector. The financial structure is thus composed of the banking industry, the formal nonbanking industry and the informal sector. The equilibrium values of prices and quantities in the banking industry determine the prices and quantities of the formal nonbanking industry, which in turn determine prices and quantities in the informal sector.

According to the model, wealth inequality in society is the essential factor explaining this dual-dual financial structure. The model then predicts market segmentation: the wealthy and the banks constitute one market, the less wealthy and formal non-banking organizations constitute another and the poorest groups and small lenders constitute the informal sector; prices are higher in the two latter sectors.

The bank credit market is quasi-Walrasian in its operation in the sense that the market clears, but for effective demand (from eligible borrowers, as determined by banks) rather than total demand. Those excluded from this market will seek credit in the regulated nonbank credit market. This second market is also quasiWalrasian because it clears, but for effective demand (from eligible borrowers as determined by the non-banking organizations) rather than total demand. Those excluded from this second market, the residual, have the option of seeking credit in the informal sector, which operates
Empirical regularities are hard to establish for informal credit. These transactions are not usually registered. However, some studies have aggregated empirical surveys and case studies in particular regions to produce some empirical regularities. Hence, Banerjee (2003) finds that credit exchange does indeed take the form of market and non-market exchange. For Latin America, a study concludes that "a plethora of reports document that microfinance institutions charge far less than informal money lenders" and reports rates of $22 \%$ a year versus $120 \%$ (cited in Campion, Rashmi-Kiran and Wenner, 2010). These facts are consistent with the predictions of the dual-dual model.

through both market and non-market transactions. In this dual-dual credit system, the poorest groups pay the highest price for credit. In sum, the three empirical regularities established at the beginning of this paper are all explained by the model.

There is now the dynamic equilibrium question. The study by Tressel (2003) is very helpful in this regard. It presents a dynamic macroeconomic model in a standard growth theory context to study the dynamics of the dual credit market over time. The basic assumptions of Tressel's model are that banks operate with collateral (as in the model used here) and that the expansion of the banking industry over time depends upon the accumulation of assets by entrepreneurs, because those assets are needed as credit collateral; hence, in his model the level and distribution of wealth also play a significant role in the development of the banking industry.

This conclusion is consistent with what would emerge from the extension of the static model presented here to a dynamic one. If the poor could accumulate capital in significant amounts, the dual-dual credit system would tend to disappear; hence, the persistence of this system in less developed countries can be taken to be the result of a process of economic growth in which wealth inequality either increases or does not decrease significantly.

The public policy implications of the model can be stated in terms of the policies that have been most commonly applied, which have not been very effective in changing the dual-dual structure, given its persistence: 
(i) government policies concentrate on the banking industry, but neglect the indirect effects on the formal non-banking market and the informal sector;

(ii) the effect of State programmes of legal security for property rights has not been significant because they do not change the inequality of wealth in society;

(iii) the effect of banking industry liberalization (absence of financial repression) has not been significant because the dual-dual structure operates even under conditions of perfect competition in the banking industry, as shown by the model developed in this paper; (iv) the current role of the State as regulator in the financial system has not had a significant effect because regulation does not impede the dual-dual credit system, as the model also shows.

Changing the dual-dual system and the type of economic growth that comes with it would require a State that was more developmental and innovative. Innovative ways of redistributing concentrated wealth and new rules and new forms of organization in the financial system are the public policies that derive from the theoretical model presented in this paper.

(Original: English)

\section{Bibliography}

Backhouse, Roger (1981), "Credit rationing in a general equilibrium model", Economica, New Series, vol. 48, No. 190, London, London School of Economics and Political Science.

Banerjee, Abhijit (2003), "Contracting constraints, credit markets, and economic development", Advances in Economics and Econometrics: Theory and Applications. Eight World Congress of the Econometric Society, Mathias Dewatripont, Lars Hansen and Stephen Turnovsky (eds.), vol. 3, Cambridge, Cambridge University Press.

Barro, Robert (1997), Macroeconomics, Cambridge, The MIT Press. Berger, Allen and others (2004), "Bank concentration and competition: an evolution in the making", Journal of Money, Credit and Banking, vol. 36, No. 6, Blackwell Publishing.

Berger, Allen and Gregory Udell (1995), "Relationship lending and lines of credit in small firm finance", The Journal of Business, vol. 68, No. 3, Chicago, The University of Chicago Press.

(1992), "Some evidence on the empirical significance of credit rationing", The Journal of Political Economy, vol. 100, No. 5, Chicago, The University of Chicago Press.

Besanko, David and Thakor Anjan (1987), "Collateral and rationing: sorting equilibria in monopolistic and competitive credit markets", International Economic Review, vol. 28, No. 3, Philadelphia, University of Pennsylvania/Osaka University Institute of Social and Economic Research Association.

Campion, Anita, Rashmi Kiran-Ekka and Mark Wenner (2010), "Interest rates and implications for microfinance in Latin America and the Caribbean", Working Paper Series, No. 177, Washington, D.C., Inter-American Development Bank.

Chan, Yuk-Shee and George Kanatas (1985), "Asymmetric valuations and the role of collateral in loan agreements", Journal of Money, Credit, and Banking, vol. 17, No. 1, Blackwell Publishing.

Djankov, Simeon, Caralee McLiesh and Andrei Shleifer (2005), "Private credit in 129 countries", NBER Working Papers, No. 11078, Cambridge, Massachusetts, National Bureau of Economic Research.

Fried, Joel and Peter Howitt (1980), "Credit rationing and implicit contract theory", Journal of Money, Credit, and Banking, vol. 12, No. 3, Blackwell Publishing.

Inderst, Roman and Holger Mueller (2007), "A lender based theory of collateral", Journal of Finance Economics, vol. 84, No. 3, Amsterdam, Elsevier.

Kiyotaki, Nobuhiro and John Moore (1997), "Credit cycles", Journal of Political Economy, vol. 105, No. 2, Chicago, University of Chicago Press.

Krugman, Paul and Robin Wells (2006), Macroeconomics, New York, Worth Publishers.

Manove, Michael, Jorge Padilla and Marco Pagano (2001), "Collateral versus project screening: a model of lazy banks", $R A N D$ Journal of Economics, vol. 32, No. 4, Santa Monica, The Rand Corporation.

Mishkin, Frederic (2007), The Economics of Money, Banking and Financial Markets, Boston, Pearson.

Morduch, Jonathan (1999), "The microfinance promise", Journal of Economic Literature, vol. 37, No. 4, Nashville, Tennessee, American Economic Association.

Steijvers, Tensie and Wim Voordeckers (2009), "Collateral and credit rationing: a review of recent empirical studies as a guide for future research", Journal of Economic Surveys, vol. 23, No. 5, Wiley-Blackwell.

Stiglitz, Joseph (2002), "Information and the change in the paradigm in economics", The American Economic Review, vol. 92, No. 3, Nashville, Tennessee, American Economic Association.

Stiglitz, Joseph and Andrew Weiss (1981), "Credit rationing in markets with imperfect information", American Economic Review, vol. 71, No. 3, Nashville, Tennessee, American Economic Association.

Tressel, Thierry (2003), "Dual financial systems and inequalities in economic development", Journal of Economic Growth, vol. 8, No. 2, New York, Springer.

Villas-Boas, Miguel and Udo Schmidt-Mohr (1999), "Oligopoly with asymmetric information: differentiation in credit markets", The RAND Journal of Economics, vol. 30, No. 3, Santa Monica, The RAND Corporation. 